\title{
Mutations in the Type II $3 \beta$-Hydroxysteroid Dehydrogenase Gene in a Patient with Classic Salt-Wasting $3 \beta$-Hydroxysteroid Dehydrogenase Deficiency Congenital Adrenal Hyperplasia
}

\author{
Y. T. CHANG, M. S. KAPPY, K. IWAMOTO, J. WANG, X. YANG, AND S. PANG \\ Deparment of Pediatrics, University of Illinois College of Medicine, Chicago Illinois 606/2 / Y.T.C.. K.I., J.UI:, \\ X.Y., S.P.J and Children's Health C'emer. St. Joseph's Hospital, Phoenix Arizona 85013 /M.S.K.J
}

\begin{abstract}
Inherited adrenal and gonadal $3 \beta$-hydroxysteroid dehydrogenase ( $3 \beta$-HSD) deficiency is most likely caused by a mutation of the type II $3 \beta$-IISD gene. Cloning and sequencing of exons I-II, III, and IV and portions of the adjacent introns, amplified by polymerase chain reaction using primers specific for the type II gene, in one male pseudohermaphrodite with salt-wasting classic $3 \beta$-ISD deficiency congenital adrenal hyperplasia revealed the same mutation in all nine clones of exon IV consisting of a missense mutation at codon 248 [GTC (Val) $\rightarrow \Lambda \Lambda C(\Lambda \mathrm{sn})]$ followed by a frameshift mutation at codon 249 |CGA $(\mathrm{Arg}) \rightarrow \mathrm{TA}$, resulting in a stop codon TAG, and normal sequences of exon I-II and III and the adjacent portions of introns. The same codon 248 and 249 mutations were found on one clone of his mother's DNA, but two other clones revealed normal sequences. These data indicate a homozygous combined missense/frameshift mutation in exon IV of the type II $3 \beta$-HSD gene resulting in severe salt-wasting adrenal and gonadal $3 \beta$-LISD deficiency in the patient. (Pediatr Res 34: 698-700, 1993)
\end{abstract}

\section{Abbreviations}

3 $\beta$-HSD, $3 \beta$-hydroxysteroid dehydrogenase

CAII, congenital adrenal hyperplasia

def, deficiency

$P C R$, polymerase chain reaction

$\triangle 5$-17P, 17-OII pregnenolone

DIIEA, dehydroepiandrosterone

17-OHP, 17-OH progesterone

$3 \beta$-HSD catalyzes the conversion of the $\Delta 5-3 \beta$-hydroxysteroids (pregnenolone, $55-17 \mathrm{P}$, DHEA, and androstenediol) to the corresponding $\Delta 4-3 \beta$-ketosteroids (progesterone, 17-OHP, androstenedione, and testosterone, respectively). Inherited $3 \beta$-HSD def is transmitted as an autosomal recessive trait and impairs adrenal and gonadal steroidogenesis $(1,2)$. Severe adrenal $3 \beta$-HSD def causes the classic salt-wasting and non-salt-wasting forms of $\mathrm{CAH}$ due to cortisol def with or without aldosterone def, respectively, and concomitant gonadal $3 \beta$-HSD def in genetic males resulting in varying degrees of sexual ambiguity due to inadequate testicular testosterone production beginning early in fetal life $(1,2)$.

Recejved for rapid publication June 8, 1993: accepted July 13,1993.

Correspondence: Ying Tai Chang. M.D., Department of Pediatrics (M/C 856).

University of Illinois College of Medicine, 840 South Wood St., Chicago, IL 60612.

Supported in part by USPHS Grant HD-24360 to the University of Illinois (S.P.) and a Biomedical Research Grant from the University of Illinois (S.P.).
Recently, two types of human $3 \beta$-HSD gene have been characterized (3-5). The type I gene has been found to be expressed in placenta, skin, and mammary gland $(3,4)$. The type II gene was found to be expressed in adrenals and gonads (5). The type I and 11 genes consist of four exons divided by three introns (6) that are $93 \%$ homologous in the coding regions (3-5) and are located on chromosome $1 \mathrm{p} 13$ (7). The nucleotide sequence of the type II gene predicts a $3 \beta$-HSD protein of 371 amino acids excluding the methionine start codon (5). To date, only one study describing mutations of the type II $3 \beta$-HSD gene in three families with $3 \beta$-HSD def CAH has been reported (8). We now report another mutation in the type II $3 \beta$-HSD gene in one patient with classic salt-wasting $3 \beta$-HSD def $\mathrm{CAH}$

\section{CASE REPORT}

The patient is a Mexican Hispanic male born at term in 1980 with a birth weight of $3.7 \mathrm{~kg}$. Small phallus $(2 \mathrm{~cm})$. 3rd-degree hypospadias, and bifid scrotum containing normal-sized testes were noted at birth. Adrenal crisis occurred on 8 with presentation of serum $\mathrm{Na}^{+} 116 \mathrm{mmol} / \mathrm{L}, \mathrm{K}^{+} 6.2 \mathrm{mmol} / \mathrm{L}, \mathrm{HCO}_{3}{ }^{-} 16$ $\mathrm{mmol} / \mathrm{L}$. Baseline serum DHEA level $(147 \mathrm{nmol} / \mathrm{L}$; normal < $42 \mathrm{nmol} / \mathrm{L}$ in newborn infants) at the time of adrenal crisis was markedly elevated. The patient did well with i.v. normal saline infusion and hydrocortisone and deoxycorticosterone acetate administration with resolution of adrenal crisis. The patient's karyotype was $46, \mathrm{XY}$. Multiple surgical repairs of the external genitalia resulted in near normalization of the hypospadias. Elevated basal $45-17 \mathrm{P}$ level $(17 \mathrm{nmol} / \mathrm{L}$; normal $<6.9 \mathrm{nmol} / \mathrm{L})$ with increased $55-17 \mathrm{P}$ to $17-\mathrm{OHP}$ ratio $(38$; normal $<3.5)$ and elevated serum DHEA level $(80 \mathrm{nmol} / \mathrm{L} ;$ normal $<7 \mathrm{nmol} / \mathrm{L})$ at age 6 y on maintenance hydrocortisone therapy further provided hormonal evidence of $3 \beta$-HSD def $\mathrm{CAH}$. Pubarche occurred at age $10 \mathrm{y}$ and the patient has been growing along the 25 th percentile in height and weight. The patient developed gynecomastia at age $11 \mathrm{y}$. At age $12 \mathrm{y}$, the patient's testes $(3-\mathrm{mL}$ volume) and penis (length $5 \mathrm{~cm}$ ) were small. The parents of the patient were reportedly not related, but both parents and their relatives as well as the grandparents were all born in the same city of Chihuahua, Mexico. The parents and the only female sibling of the proband reside in Mexico, and were reported to be healthy.

\section{METHOD}

The genomic DNA of the patient and his mother were prepared from peripheral white blood cells. Exon I through II, exon III, exon IV, and portions of the adjacent introns of the type II $3 \beta$-HSD gene were amplified by PCR using primers designed according to published type II $3 \beta$-HSD gene sequences (6). The 
amplified areas of the gene are shown in Figure 1. The primer sequences are $-22 \mathrm{~s}$ (5'-CTCCAGTCCTTCCTCCAGGG-3') and 481 a $\left(5^{\prime}-A G G T C A A C C T C C C C A C A C C C-3^{\prime}\right)$ for exon I.II; 3998s $\left(5^{\prime}\right.$-TCACGGATGTGTGACAATTC-3') and 4478a $\left(5^{\prime}\right.$ CTGATCCTCATTTAACCAAC $\left.-3^{\prime}\right)$ for exon III: and $6596 \mathrm{~s}\left(5^{\prime}\right.$ CATGTGGTTGCAGCTCCTTT-3') and 7615a (5'-GAAGAAGACAGTAAGTTGGG-3') for exon IV. The thermocycling of PCR was $95^{\circ} \mathrm{C}$ for $1 \mathrm{~min}, 56^{\circ} \mathrm{C}$ for $1 \mathrm{~min}$, and $72^{\circ} \mathrm{C}$ for $1 \mathrm{~min}$ for 30 cycles for exon I and II. The annealing temperature was $50^{\circ} \mathrm{C}$ instead of $56^{\circ} \mathrm{C}$ for exons III and IV. The PCR products were run on agarose gel for verification of the predicted DNA sizes and then subcloned into plasmid vectors and transformed into competent Escherichia coli cells using the TA Cloning Kit from Invitrogen Inc. (San Diego, CA). Plasmid DNA was sequenced by the dideoxynucleotide method using Sequenase Version 2.0 from USB Lab (Cleveland, $\mathrm{OH}$ ). The primers for the sequencing were the same as those for $\mathrm{PCR}$, with an addition of two internal primers, $6881 \mathrm{~s}\left(5^{\prime}\right.$-ACCTTGTACACTTGTGC- $\left.3^{\prime}\right)$ and $7301 \mathrm{a}\left(5^{\prime}\right.$-TGTGGCGGTTGAAGGG-3'), for sequencing the middle region of exon IV.

\section{RESUITS}

Sequencing of all nine clones of exon IV from the patient revealed a missense mutation at codon 248 [GTC $(\mathrm{Val}) \rightarrow$ AAC (Asn)] and a frameshift mutation at codon 249 [CGA (Arg) $\rightarrow$ TA] resulting in a stop codon TAG (Fig. 2). The possibility that

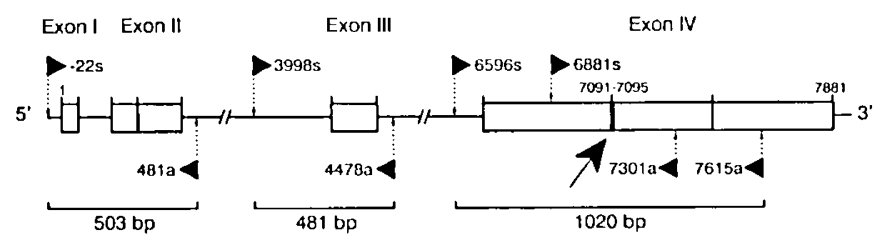

Fig. 1. Schematic of primers $(4$ and $>$ ) designed for PCR amplification and sequencing analysis of the $1 y p e$ II $3 \beta$-HSD gene. All primers were used for both PCR and sequencing except 6881 s and $7301 \mathrm{a}$, which were used for sequencing only. $s$ indicates sense strand; $a$ indicates antisense strand. Numbers just above the exon/intron boxes indicate nucleotide numbers. The boxes represent exons, with the shaded areas indicating coding regions and rmshaded areas indicating untranslated regions. The areas betwe'n boxes represent introns. The vertical line in the shaded area of Exon IV (bp 7091-7095) indicated by an arrow is the site of mutation in the patient.

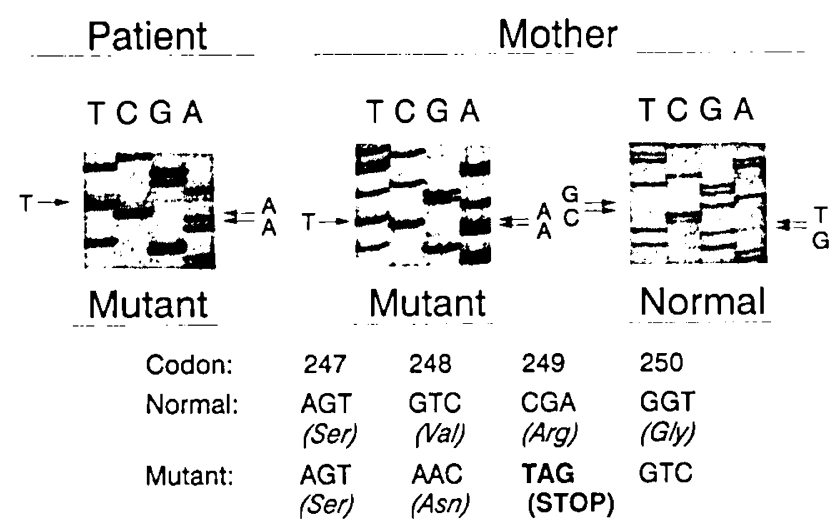

Fig. 2. Sequencing of exon IV of the type II $3 \beta$-HSD gene demonstrating identical mutations on all nine clones from the patient with classic salt-wasting 3 3 -HSD def $\mathrm{CAH}$ and the same mutation in one clone from the patient's mother with two normal clones from the mother's DNA. These data indicate the presence of the homozygous mutation on the $3 \beta$-HSD gene in the patient and heterozygous mutation in the patient's mother. these mutations are artifacts generated during PCR was excluded by repetition of PCR, subcloning. and sequencing. Sequencing of exons I to III, including portions of adjacent introns, of the type II gene in the patient revealed normal sequences. These results suggest a homozygous combined mutation consisting of missense and frameshift mutations at codons 248 and 249 in this patient. Sequencing analysis of one clone of exon IV of the type II $3 \beta$-HSD gene from his mother also revealed the same mutation as that found in the patient, but two other clones revealed normal sequences, confirming the presence of a heterozygous mutation state in the mother.

\section{DISCUSSION}

In this genetic male, the presentation of the ambiguous genitalia, the salt-wasting adrenal crisis, markedly elevated serum DHEA during the neonatal period, and elevated DHEA and $د 5$ $17 \mathrm{P}$ levels with elevated $\Delta 5-17 \mathrm{P} / 17-\mathrm{OHP}$ ratio during childhood while on maintenance hydrocortisone therapy were consistent with severe classic adrenal and gonadal $3 / 3$-HSD def. The mutation of the type II $3 \beta-\mathrm{HSD}$ gene identified in this patient provides the molecular basis of the severe $3 \beta$-HSD def affecting both adrenal and gonadal steroidogenesis in the patient. The molec-. ular findings of the type II $3 \beta$-HSD gene mutation in a few other $3 \beta$-HSD def patients were recently reported (8). A nonsense mutation at codon 171 in two families was reported. In another family, the same nonsense mutation was found on one allele, and an insertion of a single base between codons 186 and 187 resulted in a frameshift leading to a stop codon at codon 202 in the other allele (8). In our patient, a missense mutation at codon 248 was followed by a change of two nucleotides including a deletion of one $C$ or $G$ and substitution by $T$ resulting in a stop codon at codon 249 . The missense mutation at codon 248 results in an altered amino acid 247 and the frameshift mutation at codon 249 yields a stop codon resulting in a predictable truncated type II $3 \beta$-HSD protein of 247 amino acids instead of the normal 371 amino acids. Both alleles likely bear the same mutation because the probability of sequencing the same allele in nine clones is only 0.00195 . In addition, complete sequencing of three clones of exons I to III did not reveal any mutation. The same mutation in exon IV of the type II $3 \beta$-HSD gene found in one allele but not the other allele from the mother confirmed the heterozygosity of this mutation in the mother. Thus, the combined missense/frameshift mutation on both alleles of the gene found in our patient was associated with severe adrenal and gonadal $3 \beta$-HSD def as was demonstrated in the patient. Although the genesis of this mutation is not presently understood, the data provide additional information on the molecular basis of salt-wasting classic $3 \beta$-HSD def CAH.

Acknowledgment. The authors thank Eric St. Clair for his technical assistance.

\section{REFERENCES}

1. Miller WL. Levine LS 1987 Molecular and clinical advances in congenital adrenal hyperplasia. J Pediatr 111:1-17

2. Pang S, Levine I.S, Stoner E. Optiz JM, Pollack MS. Dupont B. New MI 1983 Nonsalt-losing congenital adrenal hyperplasia due to 3/3-hydroxysteroid dehydrogenase deficiency with normal glomerulosa function. J Clin Endocrinol Metab 56:808-818

3. Lorence MC, Murry BA. Trant JM, Mason JI 199() Human 3/3-hydroxysteroid dehydrogenase $/ \Delta^{5-1}$ isomerase from placenta: expression in nonsteroidogenic cells of a protein that catalyzes the dehydrogenation/isomerization of C21 and C19 steroids. Endocrinology 126:2493-2498

4. Lachance Y. Luu-The V. Labrie C. Simard J. Dumont M, de Launoit Y' Guerin S. Leblanc G, Labrie F 1990 Characterization of human 3/3-hydroxysteroid dehydrogenase/ $\left.د^{5}-\right\lrcorner^{4}$-isomerase gene and its expression in mammalian cells. J Biol Chem 265:20469-20475

5. Rheatume E, Lachance $Y$, Zhao HIF. Breton N. Dumont M. de Launoit Y'. Trudel C. Luu-The V. Simard J. Labrie F 1991 Structure and expression of a new complementary DNA encoding the almost exclusive $3 ;$-hydroxyste- 
roid dehydrogenase/ $15-14$-isomerase in human adrenals and gonads. Mol Endocrinol 5:1147-1157

6. Lachance Y, Luu-The V. Verreault H, Dumont M. Rhéaume E. Leblanc G, Labrie F 1991 Structure of the human type II $3 \beta$-hydroxysteroid dehydrogenase/ $\triangle 5-\Delta 4$ isomerase ( $3 \beta$-HSD) gene: adrenal and gonadal specificity. DNA Cell Biol 10:701-711
7. Berube D, l.uu-The V. Lachance Y, Gagne R, Labrie F 1989 Assignment of the human $3 \beta$-hydroxysteroid dehydrogenase gene (IISDB3) to the p1.3 band of chromosome 1. Cytogenet Cell Genet 52:199-200

8. Rhéaume E, Simard J, Morel Y, Mebarki F, Zachmann M. Forest MG, New MI, Labrie F 1992 Congenital adrenal hyperplasia due to point mutations in the type $113 \beta$-hydroxysteroid dehydrogenase gene. Nat Genet 1:239-245

\section{Announcement}

\section{Call for Abstracts}

The American Pediatric Society and The Society for Pediatric Research announce the abstract deadline for the 1994 Annual Meeting (May 2-5, 1994, Washington State Convention and Trade Center) has been set as Jamuary' 4, 1994.

For further information, contact: APS/SPR Association Headquarters, 141 Northwest Point Blvd., P.O. Box 675, Elk Grove Village, IL 60009-0675. (708) 427-0205. Fax: (708) 427-1305. 